\title{
Mist Level Influences Vapor Pressure Deficit and Gas Exchange During Rooting of Juvenile Stem Cuttings of Loblolly Pine
}

\author{
Anthony V. LeBude, ${ }^{1}$ Barry Goldfarb, ${ }^{2}$ Frank A. Blazich, ${ }^{3}$ \\ John Frampton, ${ }^{4}$ and Farrell C. Wise ${ }^{5}$ \\ Department of Forestry, North Carolina State University, Raleigh, NC 27695-8002
}

Additional index words. clonal forestry, vegetative propagation, Pinus taeda, water relations

Abstract. Two experiments were conducted during which juvenile hardwood or softwood stem cuttings of loblolly pine (Pinus taeda L.) were rooted under six mist regimes in a polyethylene-covered greenhouse to investigate the effect of mist level on vapor pressure deficit (VPD) and cutting water potential $\left(\Psi_{\text {cut }}\right)$, and to determine the relationships between these variables and rooting percentage. In addition, net photosynthesis at ambient conditions $\left(\mathrm{A}_{\text {ambient }}\right)$ and stomatal conductance $\left(\mathrm{g}_{\mathrm{s}}\right)$ were measured in stem cuttings during adventitious root formation to determine their relationship to rooting percentage. Hardwood stem cuttings rooted $\geq 80 \%$ when mean daily VPD between 1000 and $1800 \mathrm{HR}$ ranged from 0.60 to 0.85 $\mathrm{kPa}$. Although rooting percentage was related to $\Psi_{\text {cut }}$, and $\mathrm{A}_{\text {ambient }}$ was related to $\Psi_{\text {cut }}$, rooting percentage of softwood stem cuttings was not related to $A_{\text {ambient }}$ of stem cuttings. Using VPD as a control mechanism for mist application during adventitious rooting of stem cuttings of loblolly pine might increase rooting percentages across a variety of rooting environments.

Loblolly pine (Pinus taeda) is the most important timber species in the southeast United States. Adventitious rooting of stem cuttings of loblolly pine collected from stock plants in the juvenile growth phase can be used to multiply superior genotypes (clones) within families for progeny testing in breeding programs (Isik et al., 2004), or for use directly in reforestation (Frampton et al., 2000, 2002). Loblolly pine has been considered recalcitrant to propagate by stem cuttings (Zobel and Talbert, 1984) and somatic embryogenesis (Pullman et al., 2003), posing an obstacle to large-scale use in clonal forestry. For vegetative propagation of stem cuttings of loblolly pine to attain operational levels, successful rooting must be accomplished in low-cost environments. Several propagation environments, including greenhouses, shadehouses, and nursery beds are being tested (Gocke, 2001). Abiotic factors, such as rooting substrate, mist application, air

Received for publication 5 Dec. 2004. Accepted for publication 25 Jan. 2005. This research was funded jointly by the industrial supporters of the North Carolina State University Loblolly and Slash Pine Rooted Cutting Program and by the North Carolina Agricultural Research Service (NCARS) Raleigh, NC 27695-7643. Use of trade names in this publication does not imply endorsement by the NCARS of the products named nor criticism of similar ones not mentioned. Statistical assistance of Cavell Brownie, and technical assistance of Kelly Dougherty, Jim Grissom, and Neil LeBude is greatly appreciated. From a thesis to be submitted by A.V.L. in partial fulfillment of the requirements for the $\mathrm{PhD}$ degree.

${ }^{1}$ Research assistant.

${ }^{2}$ Professor and head.

${ }^{3}$ Professor, Department of Horticultural Science.

${ }^{4}$ Associate professor.

${ }^{5}$ Former research scientist and project leader, MeadWestvaco Corp., Box 1950 Summerville, SC 29484. temperature, wind, relative humidity $(\mathrm{RH})$, and irradiance can vary among these environments and affect rooting percentage. Thus, irrigation schedules that are optimized for one rooting environment may not be successful in others. Understanding how environmental factors induce the physiological responses associated with increased rooting could enable propagators to reproduce those conditions utilizing a variety of production systems.

LeBude et al. (2004) determined previously that, provided substrate water potential was -2.4 $\pm 0.2 \mathrm{kPa}$, mist level was the most important factor influencing rooting percentage of juvenile stem cuttings of loblolly pine. Mist level was strongly related to cutting water potential $\left(\Psi_{\text {cut }}\right)$, a physiological indicator of water deficit, and $\Psi_{\text {cut }}$ was related to rooting percentage. They hypothesized that stem cuttings of loblolly pine need to experience a moderate, mean daily water deficit to stimulate adventitious root formation and development. Using $\Psi_{\text {cut }}$ as an indicator of rooting percentage, however, would be cumbersome in an operational system because measurements are labor intensive.

Vapor pressure deficit (VPD) has been used successfully to control mist frequency dynamically on stem cuttings of 'Freedom Dark Red' poinsettia (Euphorbia pulcherrima Willd. Ex Klotzsch 'Freedom Dark Red') during the transition period between root emergence and subsequent root growth (Zolnier et al., 2001a; 2003). Although VPD has been monitored during rooting of stem cuttings in other species, correlations between VPD, rooting percentage, and $\Psi_{\text {cut }}$ were not intended as objectives of various studies (Aminah et al., 1997; Grossnickle and Russell, 1993; Newton et al., 1992). An initial step in using an environmental factor to control mist application or predict rooting success is to define the response of stem cut- tings to that factor (Zolnier et al., 2001b). Such research has not been reported for stem cuttings of loblolly pine.

Current photosynthesis (photosynthetic rate of stem cuttings during the period of adventitious root formation and development) and stomatal conductance to water vapor $\left(g_{\mathrm{s}}\right)$ are two physiological variables that may influence adventitious root formation in stem cuttings (Davis, 1988). Photosynthetic rate in stem cuttings is dependent upon a complex interaction among the level of photosynthetically active radiation $(P A R), \mathrm{RH}$, stomatal opening, and water potential (Davis, 1988). Because $\Psi_{\text {cut }}$ is associated with rooting percentage (Hartmann et al., 2002; LeBude et al., 2004; Loach and Whalley, 1978), its effect on current photosynthesis might explain the relationship between $\Psi_{\text {cut }}$ and rooting percentage. Moreover, the relationship between these processes might aid design of rooting environments to induce photosynthetic responses in stem cuttings associated with increased rooting percentages.

The experiments in this report were conducted concurrently with the experiments of LeBude et al. (2004) using the same stem cuttings, rooting environments, and mist treatments. The goal of this report is to first broaden the impact of LeBude et al. (2004) by developing quantitative information for controlling rooting environments, and secondly, to describe further the nature of the relationship between $\Psi_{\text {cut }}$ and rooting percentage by studying gas exchange in stem cuttings. Therefore, the following two experiments were conducted to determine 1) the relationships between VPD and $\Psi_{\text {cut }}$, and VPD and rooting percentage, and to determine 2) the relationship between gas exchange and adventitious rooting of juvenile stem cuttings of loblolly pine.

\section{Materials and Methods}

Plantmaterial. The provenance, propagation and culture of stock plants, and subsequent collection of stem cuttings for these experiments, were described previously (LeBude et al., 2004). Methods described for Expts. 3 and 4 in LeBude et al. (2004) are the same for Expts. 1 and 2 in the present study. Briefly, either juvenile hardwood (Expt. 1) or juvenile softwood (Expt. 2) terminal stem cuttings were collected and bulked from recurrently sheared (hedged) stock plants of two full-sib families of loblolly pine, and then placed in insulated coolers. For Expt. 1, the coolers were placed in a cold room and maintained at $4{ }^{\circ} \mathrm{C}$ for 8 weeks until setting the cuttings (insertion into the rooting substrate) on 5 Apr. 2002, whereas in Expt. 2, the coolers were placed under a greenhouse bench overnight until the cuttings were set the following day, 29 June 2002. Before setting cuttings to a depth of $1 \mathrm{~cm}$, cuttings were recut from the proximal ends to a final length of 9 $\mathrm{cm}$, and the basal $1 \mathrm{~cm}$ was dipped for $3 \mathrm{~s}$ in either $10 \mathrm{~mm}$ 1-naphthaleneacetic acid (NAA; $1.86 \mathrm{~g} \cdot \mathrm{L}^{-1}$ in $30 \%$ ethanol $\mathrm{v} / \mathrm{v}$ ) for Expt. 1, or $2.5 \mathrm{mM}$ NAA $\left(0.46 \mathrm{~g} \cdot \mathrm{L}^{-1}\right.$ in $20 \%$ ethanol $\left.\mathrm{v} / \mathrm{v}\right)$ for Expt. 2. Needles were not removed from the basal portions of the cuttings that were inserted into the rooting medium. 
Rooting environment. Both experiments were conducted under natural photoperiod and irradiance in a clear polyethylene-covered greenhouse; however, irradiance in Expt. 2 was decreased $60 \%$ by placing shade cloth on the greenhouse exterior. Heating and cooling systems were adjusted to maintain the daily air temperature between 23 and $26{ }^{\circ} \mathrm{C}$ and the night temperature between 20 and $23{ }^{\circ} \mathrm{C}$. Cuttings were misted intermittently at a variable frequency related inversely to the RH (50-Y Temp/RH Probe, QCOM Corp., Irvine, Calif.) surrounding stem cuttings being rooted on an adjacent bench within the greenhouse. The Temp/RH probe was also misted with $121 \mathrm{~mL} \cdot \mathrm{m}^{-2}$ of mist at each boom pass. Variable frequencies were defined by designating minimum $(60 \% \mathrm{RH})$ and maximum $(99 \% \mathrm{RH})$ off-times between mist applications. Off-times for intermediate humidity values were calculated using a linear function. The minimum and maximum off-times varied according to the time of day. For the period from 0600 to 0900 $\mathrm{HR}$, the minimum and maximum off times were 10 and $35 \mathrm{~min}$, respectively. For the periods from 0900 to $1800 \mathrm{HR}, 1800$ to $2100 \mathrm{HR}$, and 2100 to $0600 \mathrm{HR}$, minimum and maximum off times were 8 and $24 \mathrm{~min}, 10$ and $40 \mathrm{~min}$, and 60 and $240 \mathrm{~min}$, respectively. A greenhouse environmental management software program (GEM3; QCOMCorp., Irvine, Calif.) calculated mist frequency and triggered a traveling gantry (boom) (Solaris; McConkey Co., Mt. Puyallup, Wash.) to apply mist. Misting frequency (number of boom passes) was similar for all cuttings within each experiment; however, boom traveling speeds were altered to create different mist application treatments. For each boom speed, mist application was calculated by dividing the total output for all nozzles $\left(258 \mathrm{~mL} \cdot \mathrm{min}^{-1}\right.$ per nozzle $\times 26$ nozzles) (TeeJet nozzle $\# 800067$; Spraying Systems, Co., Neuvo, Calif.) by the area covered by the boom in $1 \mathrm{~min}$, expressed as milliliters per square meter. The experimental design was a randomized complete block with two replications of mist. The mist treatments were $45,61,75,102,147$, or $310 \mathrm{~mL} \cdot \mathrm{m}^{-2}$ of mist per boom pass. Each plot was divided by clear polyethylene plastic barriers $(91.4 \mathrm{~cm}$ tall $)$ to minimize environmental gradients within the greenhouse and to separate treatments. Experimental stem cuttings were surrounded by two rows of border cuttings of the same genetic origin.

Dependent variables. A pressure chamber (Scholander et al., 1965) (SoilMoisture Equipment Corp., Santa Barbara, Calif.) was used to measure $\Psi$ destructively every $3 \mathrm{~h}$ beginning at 0500 until $2300 \mathrm{HR}$ (seven measurements) on two cuttings per plot 7, 14, 21, 28, or 35 (Expt. 2 only) d after setting (DAS). Data for both cuttings were subsequently averaged to provide a mean for each plot per measurement time. Substrate water potential $\left(\Psi_{\text {sub }}\right)$ was also measured in each plot using a tensiometer (Irrometer Co., Riverside, Calif.) at 0500 and $1400 \mathrm{HR}$ on the same days that $\Psi_{\text {cut }}$ was measured; however, $\Psi_{\text {sub }}$ was not significantly different among plots [data not presented, see LeBude et al. (2004) for construction and maintenance of $\left.\Psi_{\text {sub }}\right]$. Cuttings selected randomly for $\Psi_{\text {cut }}$ measurements were replaced to maintain canopy dynamics, but were excluded from subsequent measurements. Adventitious roots began to emerge about 28 to 42 DAS; however, the percentage of cuttings producing at least one root $\geq 1 \mathrm{~mm}$ was recorded for each plot 70 DAS.

Effect of mist level on VPD, and VPD on $\Psi_{\text {cut }}$ and rooting percentage (Expt. 1). Leaf temperatures were recorded in all plots continuously using thermocouples (Type-T; Omega Engineering, Stamford, Conn.) connected to a micrologger(23X; Campbell Scientific, Logan, Utah). RH at the stem cutting level was recorded in each mist plot in the second replication only by six separate HOBO data loggers (Onset Computer Corp., Pocasset, Mass.). Data for leaftemperature and $\mathrm{RH}$ were averaged continuously from both data loggers over 15-min intervals. VPD based on the leaf temperature and $\mathrm{RH}$ was calculated using equations of Buck (1981) and Prenger and Ling (2001). Leaf temperature was used as a substitute for air temperature because leaf temperature was measured in both replications and air temperature and humidity in one replication only. Because VPD was calculated for each plot using this method, data for VPD were averaged over both replications before analyses to account for this limitation. In some cases, HOBO data loggers malfunctioned while data were being recorded due to either saturated conditions or battery failure. As a result, data for the mist level of $61 \mathrm{~mL} \cdot \mathrm{m}^{-2}$ were excluded from all analyses and data for the mist level of $75 \mathrm{~mL} \cdot \mathrm{m}^{-2}$ include only the first 20 DAS rather than 30 DAS used for all other mist levels. Although VPD was recorded in Expt. 2, data logger malfunction prevented data from being retrieved for use. Therefore, data for VPD in Expt. 2 are not presented.

Mean VPD between 1000 and 1800 HR was used in analyses, because the greatest variation among mist levels occurred during this period and, subsequently, was found to contribute most meaningfully to the statistical relationships between variables. Likewise, mean $\Psi_{\text {cut }}$ for measurements at 1100,1400 , or 1700 HR were used to coincide with this time frame. Previously, rooting percentage was found to be related to mean daily $\Psi_{\text {cut }}$ averaged from 0500 to 2300 $\mathrm{HR}$, and related to the single daily minimum $\Psi$ (most negative) measured (LeBude et al., 2004). The present paper differs by reporting the relationship between the environmental conditions during rooting that contribute to the mean midmorning to late afternoon $\Psi$

Effect of mist level on photosynthesis at ambient conditions $\left(A_{\text {ambien }}\right)$ and stomatal conductance to water vapor $(g)$ and their effect on rooting percentage (Expt. 2). $\mathrm{A}_{\text {ambient }}$ and $\mathrm{g}_{\mathrm{s}}$ were measured on nonrooted stem cuttings 14 , $28,42,56$, or 70 DAS using a LI-6400 infrared gas analyzer (IRGA) (Software version Open 3.4, LI-COR, Lincoln, Nebr.) equipped with a 6- $\mathrm{cm}^{2}$ cuvette and a 6400-02B red-blue LED light source. The same measurements were made separately on rooted stem cuttings (control plants) 28 or 70 DAS only. All measurements were recorded on a replication basis between 0750 and $1100 \mathrm{HR}$ (AM) and 1300 and $1600 \mathrm{HR}$ (PM) on two nonrooted stem cuttings per plot, or on two random plants per plot in the case of controls (i.e., data for replication 1 of nonrooted stem cuttings were recorded 27 DAS, while data for replication 1 of the controls were recorded 28 DAS, etc.). For AM and PM measurements, the average ambient greenhouse environmental conditions across plots (as recorded by dataloggers and QCOM for 2 weeks before the first measurements) were reproduced in the cuvette and used as a standard environment for measurement. During all AM measurements, $P A R$ was held constant at $250 \mu \mathrm{mol} \cdot \mathrm{m}^{-2} \cdot \mathrm{s}^{-1}, \mathrm{CO}_{2}$ was $400 \mu \mathrm{mol} \cdot \mathrm{m}^{-2} \cdot \mathrm{s}^{-1}$, RH was $74 \%$ to $79 \%$, and leaf temperature was $25^{\circ} \mathrm{C}$. During all PM measurements, $P A R$ was $450 \mu \mathrm{mol} \cdot \mathrm{m}^{-2} \cdot \mathrm{s}^{-1}, \mathrm{CO}_{2}$ was $400 \mu \mathrm{mol} \cdot \mathrm{m}^{-2} \cdot \mathrm{s}^{-1}$, RH was $64 \%$ to $69 \%$, and leaf temperature was $28^{\circ} \mathrm{C}$.

Cuttings were selected randomly from plots and hand dried with paper towels and KimWipes (Kimberly Clark, Inc., Neenah, Wis.). Because we expected rates of $\mathrm{CO}_{2}$ assimilation and $g_{s}$ to be low and variable for stem cuttings, we inserted as many recently expanded needles into the cuvette as possible without overlapping. Leaf area on the IRGA was set to $2 \mathrm{~cm}^{2}$ for all measurements, and then readjusted based on leaf area calculations described below. Before logging data, $A_{\text {ambient }}$ and $g_{\mathrm{s}}$ were monitored for 3 to $5 \mathrm{~min}$ while the total coefficient of variation was $<0.5 \%$. $\Psi_{\text {cut }}$ was measured immediately on each stem cutting or control plant, using a pressure chamber, after measurements of gas exchange were completed.

Controls. From Expt. 1, 144 rooted stem cuttings (originally from the same stock plants as stem cuttings used in Expt. 2) were chosen randomly from a larger group of rooted cuttings and potted in 164-mL Ray-Leach SuperCells (Steuwe and Sons, Corvallis, Ore.) filled with the same silica sand used for rooting the stem cuttings. The rooted cuttings were grown outdoors for 3 weeks and fertilized daily with a $20 \mathrm{~N}-8.7 \mathrm{P}-16.6 \mathrm{~K}$ water soluble fertilizer (Peters, The Scotts Co., Marysville, Ohio) providing $\mathrm{N}$ at $100 \mathrm{mg} \cdot \mathrm{L}^{-1}$. Plants were then topdressed with $0.71 \mathrm{~g} 18 \mathrm{~N}-2.6 \mathrm{P}-9.9 \mathrm{~K}$ Osmocote controlled-release fertilizer (8 to 9 month formulation, Grace-Sierra, Milpitas, Calif) and placed beside nonrooted stem cuttings under eachmist treatment. Control plants were watered twice daily over the entire experiment to maintain similar substrate water contents as rooting tubs receiving subirrigation. Substrate water potential was not measured in controls.

Fasciclesurface area in the cuvette. Fascicle surface area (SA) was estimated using the equation, $\mathrm{SA}=2 \pi \mathrm{rl}+6 \mathrm{rl}$, which assumes needles are the sectors of a cylinder, and $r$ is the radius in centimeters of the fascicle (measured as the interior face of one needle in the fascicle of three needles) and 1 is the length of the needle in centimeters (Johnson, 1984; Svenson and Davies, 1992). During measurements of $\mathrm{CO}_{2}$ assimilation $42 \mathrm{DAS}$, one fascicle consisting of three needles was selected independently of experimental fascicles within each replication $\times$ time-of-day measurement $[2$ cuttings per plot $\times 2$ replications $\times 2$ times of day (AM and $\mathrm{PM}$ ) equals eight cuttings (eight fascicles) for each mist level]. Fascicles were cut to a length of 31 mm representing the length and portion of needle enclosed in the $2 \times 3 \mathrm{~cm}$ cuvette. A thin cross 
Table 1. Analysis of variance summary for potential effects of mist level (M), days after setting (DAS), and time of day (TOD) on photosynthetic rate $\left(\mathrm{A}_{\text {ambient }}\right)$ and stomatal conductance $\left(\mathrm{g}_{\mathrm{s}}\right)$ of nonrooted, juvenile, softwood stem cuttings of loblolly pine in Expt. 2 (conducted June 2002) 14, 28, 42, 56, or 70 DAS, and of intact, rooted control plants evaluated 28 or 70 DAS. Values are the probability of a greater $\mathrm{F}$ statistic. Bold values are statistically significant at $P<0.05$.

\begin{tabular}{lrcccccc}
\hline & \multicolumn{3}{c}{ Nonrooted cuttings } & & \multicolumn{3}{c}{ Rooted controls } \\
\cline { 2 - 4 } \cline { 6 - 7 } Source & $\mathrm{df}$ & $\mathrm{A}_{\text {ambient }}$ & $\mathrm{g}_{\mathrm{s}}$ & & $\mathrm{df}$ & $\mathrm{A}_{\text {ambient }}$ & $\mathrm{g}_{\mathrm{s}}$ \\
\hline Replication & 1 & $\mathbf{0 . 0 2}$ & 0.23 & & 1 & $\mathbf{0 . 0 2}$ & 0.10 \\
$\mathrm{M}$ & 5 & $\mathbf{0 . 0 1}$ & $\mathbf{0 . 0 1}$ & & 5 & 0.40 & 0.55 \\
$\mathrm{DAS}$ & 4 & $\mathbf{0 . 0 2}$ & $\mathbf{0 . 0 4}$ & & 1 & $\mathbf{0 . 0 1}$ & $\mathbf{0 . 0 3}$ \\
TOD & 1 & 0.54 & 0.31 & & 1 & 0.93 & 0.38 \\
$\mathrm{DAS} \times \mathrm{M}$ & 20 & 0.13 & 0.52 & & 5 & 0.43 & 0.51 \\
TOD $\times$ M & 5 & 0.92 & 0.71 & & 5 & 0.43 & 0.75 \\
$\mathrm{DAS} \times$ TOD & 4 & 0.42 & 0.45 & & 1 & 0.53 & 0.46 \\
DAS $\times$ TOD $\times \mathrm{M}$ & 20 & 0.85 & 0.87 & & 5 & 0.50 & 0.37 \\
\hline
\end{tabular}

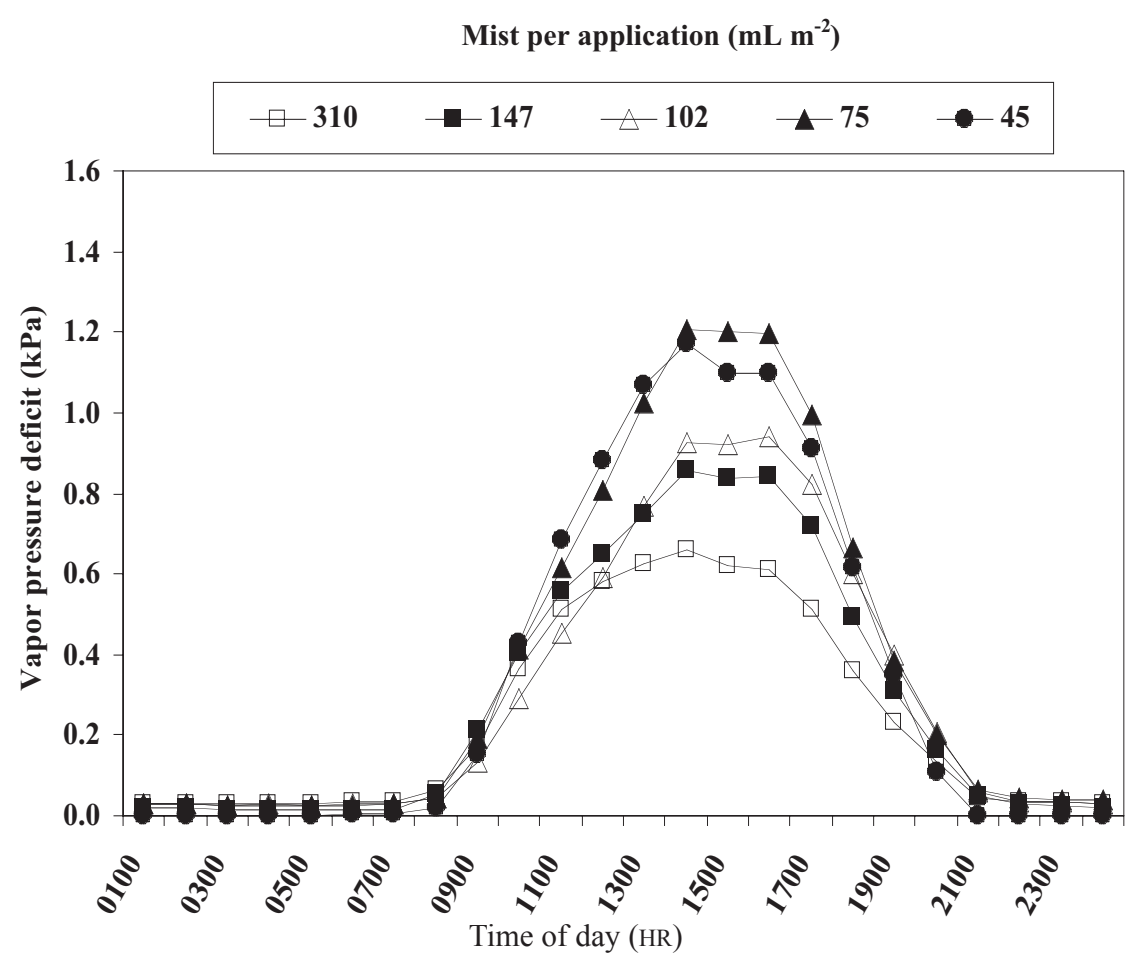

Fig. 1. Effect of mist level on mean vapor-pressure deficit (VPD) by hours over $20\left(75 \mathrm{~mL} \cdot \mathrm{m}^{-2}\right)$ or $30 \mathrm{~d}$ after setting (DAS) for Expt. 1 (April 2002). Mist level of $61 \mathrm{~mL} \cdot \mathrm{m}^{-2}$ was not included due to instrument error while data were recorded. Symbols are means of two replications.

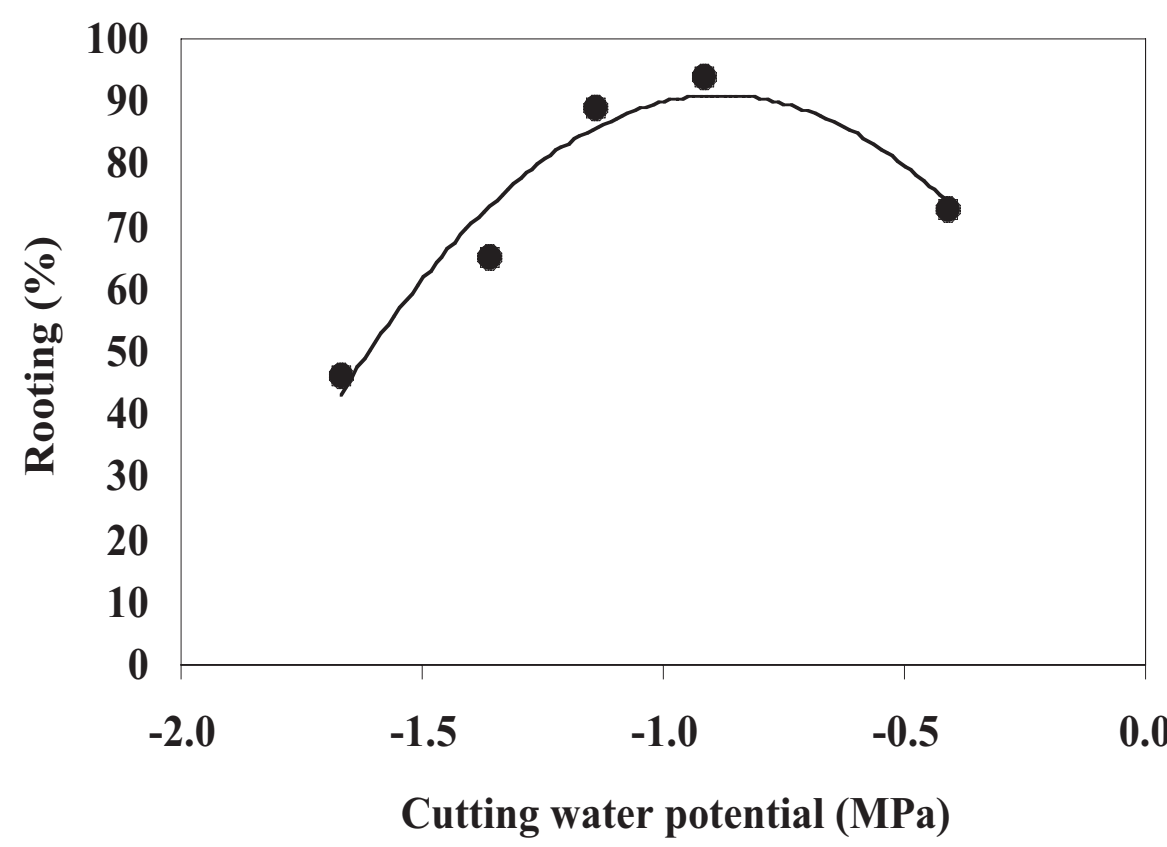

section was taken from the midsection of each needle as well as each end yielding an average measure of the radius of the proposed cylinder based on nine measurements for each fascicle. The interior face of each cross section was measured to the nearest $0.1 \mathrm{~mm}$ using a stereo microscope (Wild HeerBrugg, Technical InstrumentCo., San Francisco, Calif.). The remaining $30 \mathrm{~mm}$ length of needle was dried for $72 \mathrm{~h}$ at 70 ${ }^{\circ} \mathrm{C}$ and weighed to the nearest $0.01 \mathrm{mg}$. SA was then regressed on the dry weight (DW) of each fascicle-by-mist treatment. The resulting regression equations were used to estimate SA based on the DW of needles actually used in measurements of gas exchange from all measurement periods. SA was estimated similarly for needles collected from control plants at 70 DAS. After SA was estimated for all measurement periods and both plant types, data for $\mathrm{A}_{\text {ambient }}$ and $\mathrm{g}_{\mathrm{s}}$ were recalculated using the IRGA by re-entering the leaf area measurements.

Statistical analyses. Data were tested for normality and homogeneity of variances using univariate procedures (Steel et al., 1997) in SAS v. 8.2 (SAS Institute, Inc., 2001). Data for $A_{\text {ambient }}$ were distributed normally and had homogeneous variances; however, data for $\mathrm{g}_{\mathrm{s}}$ did not. Data for $g_{s}$ were $\log$ transformed before analysis of variance (ANOVA) procedures. Nonsignificant terms for main effects and interactions were pooled into the main error term. Main effects and interactions were retested using appropriate error terms and these values are reported in Table 1. Means reported in all figures for both variables are nontransformed data.

VPD was distributed normally and had equal variances among the mist levels and time periods analyzed for this study. Data for $\Psi_{\text {cut }}$ were not distributed normally, but had equal variances among treatments. Despite numerous transformations, normality was not improved significantly. However, the transformation that improved distribution according to visual examination of plots was used in a comparative analysis with the nontransformed data. No differences were found between the two comparison analyses. Data for rooting percentage were distributed normally and had homogeneous variances among treatments. Therefore, all test statistics and means presented herein are based on the nontransformed data of $\Psi_{\text {cut }}$ and rooting percentage.

Regressionanalysis was used to determine the relationships between $\mathrm{A}_{\text {ambient }}, \mathrm{g}_{\mathrm{s}}$, rooting percentage, VPD, and $\Psi$. Each variable was used in regression either as a dependent or independent variable depending on the objective being tested. When generating the quadratic term or log

Fig. 2. Rooting percentage [70 d after setting(DAS)] as a function of $\Psi_{\text {cut }}$ averaged over both replications for measurements recorded at 1100,1400, or $1700 \mathrm{HR} 7,14,20\left(75 \mathrm{~mL} \cdot \mathrm{m}^{-2}\right.$ only $)$ or $30 \mathrm{DAS}$ for juvenile, hardwood stem cuttings rooted in Expt. 1 (April 2002). Mist level of $61 \mathrm{~mL} \cdot \mathrm{m}^{-2}$ was not included due to instrument error while data were recorded. The regression equation is as follows: rooting $(\%)=4.15-224.62\left(\Psi_{\text {cut }}\right)$ - 115.90( $\left(\Psi_{\text {cut }}{ }^{2}\right), P=0.03, r^{2}=0.97$. Data for the quadratic term $\left(\Psi_{\text {cut }}{ }^{2}\right)$ were generated by squaring the linear term and then averaging over measurement times and DAS. 

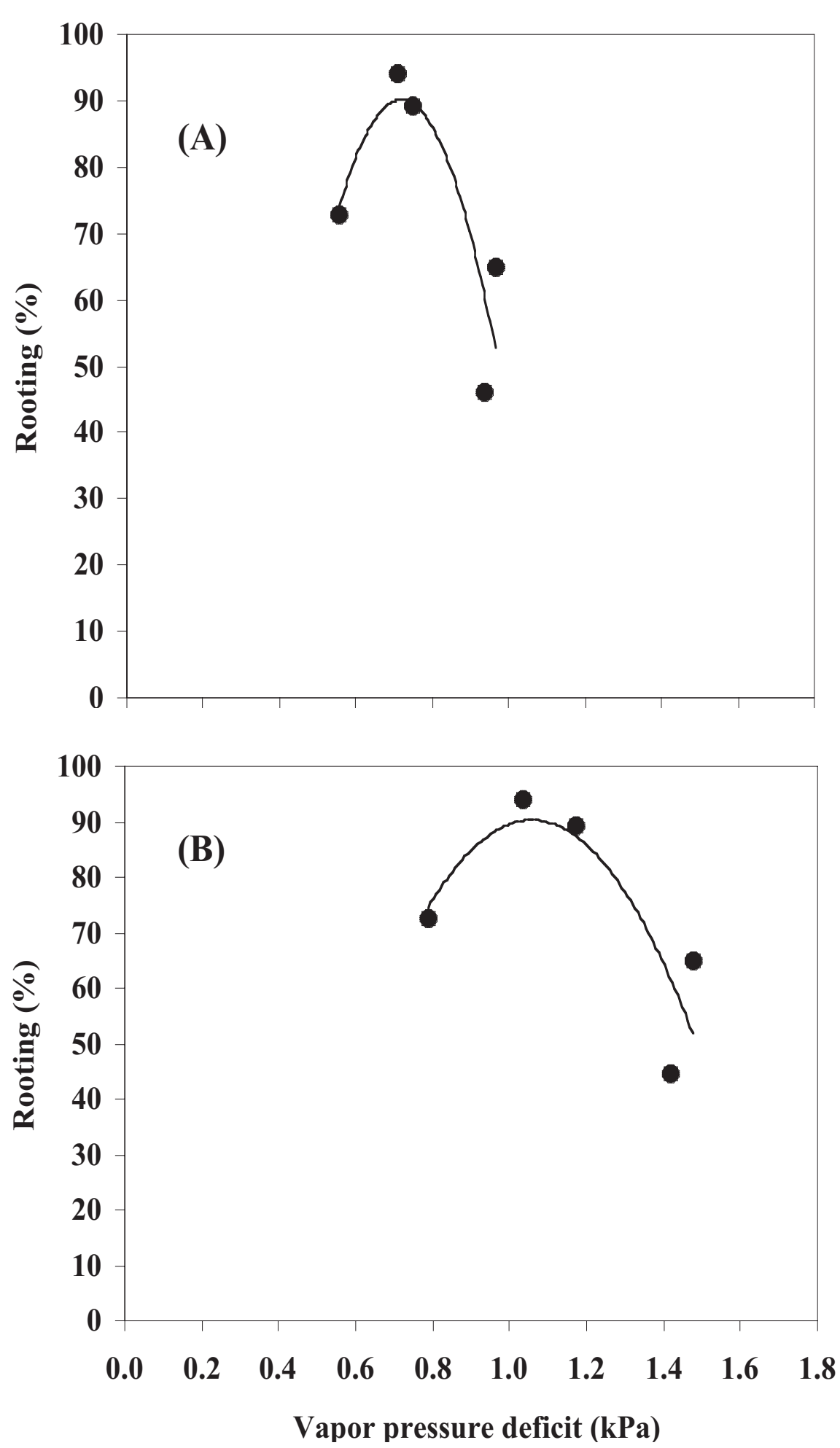

Fig. 3. Rooting percentage of juvenile, hardwood stem cuttings of loblolly pine as a function of (A) mean daily vapor-pressure deficit (VPD) between 1000 and $1800 \mathrm{HR}$, and (B) mean daily maximum VPD for one 15-min period between 1000 and $1800 \mathrm{HR}$ in Expt. 1 (April 2002). Data for VPD were averaged for both replications over $20\left(75 \mathrm{~mL} \cdot \mathrm{m}^{-2}\right.$ only) or $30 \mathrm{~d}$ after setting (DAS) and rooting was scored 70 DAS. Mist level of $61 \mathrm{~mL} \cdot \mathrm{m}^{-2}$ was not included due to instrument error while data were recorded. The regression equation for $\mathbf{A}$ is rooting $(\%)=-189.43+728.76($ mean daily VPD) $-384.88($ mean daily $\left.\mathrm{VPD}^{2}\right), P=0.04, r^{2}=0.96$, and for $\mathbf{B}$ is rooting $(\%)=-198.00+522.78$ (daily maximum VPD) -211.60 (daily maximum $\mathrm{VPD}^{2}$ ), $P=0.05, r^{2}=0.95$. Data for the quadratic term $\left(\mathrm{VPD}^{2}\right)$ were generated by squaring the linear term before averaging over measurement times and DAS.

function of a variable for use in regression, the transformation was made on the original datum and then averaged overmeasurement times, DAS, etc. For this reason, inputting variables from the

\section{Results}

Effect of mist level on VPD, and VPD on $\Psi_{\text {cu }}$ (Expt. 1). Mean VPD ranged from 0 to $1.2 \mathrm{kPa}$, depending on time of day and mist application (Fig. 1). For example, between 1300 and 1700 HR, VPD was highest for the mist level of 75 $\mathrm{mL} \cdot \mathrm{m}^{-2}(1.2 \mathrm{kPa})$ and lowest for the mist level of $310 \mathrm{~mL} \cdot \mathrm{m}^{-2}(0.6 \mathrm{kPa})$. Between 2100 and 0700 $\mathrm{HR}, \mathrm{VPD}$ was near $0 \mathrm{kPa}$ for all mist levels (Fig. 1). Averaged between 1000 and $1800 \mathrm{HR}$, VPD was strongly related to the log of mist application $\left[\mathrm{VPD}=1.81-0.22 \ln \left(\mathrm{mL} \cdot \mathrm{m}^{-2}\right), P=0.01, r^{2}=\right.$ $0.82]$. Mean $\Psi$, for measurements recorded at 1100,1400 , or $1700 \mathrm{HR}$, decreased (became more negative) as the log of VPD increased (averaged between 1000 and $1800 \mathrm{HR}$ ) $\left[\Psi_{\text {cut }}=\right.$ $\left.-1.94+1.96 \ln (\mathrm{VPD}), P=0.02, r^{2}=0.89\right]$.

Relationship between rooting percentage, $\Psi_{\text {cut }}$ and VPD (Expt. 1). Rooting percentage was strongly related to the linear and quadratic terms of $\Psi$ (Fig. 2). The regression equation predicted $\geq 80 \%$ rooting with mean $\Psi_{\text {cut }}$ between -0.55 and $-1.2 \mathrm{MPa}$ (averaged over 1100, 1400 , and $1700 \mathrm{HR}$ ). Rooting percentage was also related strongly to the linear and quadratic terms of mean daily VPD (Fig. 3A). Rooting percentages $\geq 80 \%$ occurred when mean daily VPD ranged from 0.6 to $0.85 \mathrm{kPa}$ between 1000 and $1800 \mathrm{HR}$.

The maximum daily VPD value for a single 15-min interval was recorded for each mist level and averaged 20 DAS $\left(75 \mathrm{~mL} \cdot \mathrm{m}^{-2}\right.$ only) or 30 DAS. Rooting percentage was related strongly with the linear and quadratic terms of mean maximum daily VPD (Fig. 3B). Rooting percentage was predicted $\geq 80 \%$ when daily maximum VPD ranged from 0.85 to $1.3 \mathrm{kPa}$.

Effect of mist level on $A_{\text {ambient }}$ and $g_{s}$ (Expt. 2). Mist level and DAS significantly affected $A_{\text {ambient }}$ and $g_{s}$ of nonrooted stem cuttings (Table 1). Greater mist volumes generally increased $\mathrm{A}_{\text {ambient }}$ in all five measurement periods (Fig. $4 \mathrm{~A}$ ). When $\mathrm{A}_{\text {. W }}$ was averaged for all mist levels at each measurement period, the response declined initially between 14 and 28 DAS, and then remained relatively steady through 70 DAS (see mean Fig. 4A). Stomatal conductance of nonrooted stem cuttings responded similarly to mist level and DAS (Fig. 4B). In contrast to nonrooted stem cuttings, $A_{\text {ambient }}$ and $g_{s}$ of rooted controls was affected by DAS, but not mist (Table 1.). Mean $A_{\text {ambient }}$ was 2.19 and 8.49 $\mu \mathrm{mol} \cdot \mathrm{m}^{-2} \cdot \mathrm{s}^{-1}$ at 28 and 70 DAS, respectively, and $\mathrm{g}_{\mathrm{s}}$ was 59 and $328 \mathrm{mmol} \cdot \mathrm{m}^{-2} \cdot \mathrm{s}^{-1}$ at 28 and 70 DAS, respectively, averaged across mist levels.

Photosynthesis and $g_{\mathrm{s}}$ of juvenile, nonrooted, succulent stem cuttings were related strongly to the log of mist level when data for 14, 28, or 42 DAS were averaged together to represent the period during adventitious root formation (Fig. 5A and B). Both responses increased as mist level increased. It was reported previously that daily mean $\Psi_{\text {cut }}$ was also related strongly to mist level in juvenile stem cuttings of loblolly pine (LeBude et al., 2004). In the present study, A increased linearly as $\Psi$ increased (became less negative) (Fig. 6A ). Stomatal conductance, however, had a different response to $\Psi_{\text {cut }}$, increasing gradually $\left(35 \mathrm{mmol} \cdot \mathrm{m}^{-2} \cdot \mathrm{s}^{-1}\right)$ 


\section{Mist per application $\left(\mathrm{mL} \mathrm{m}^{-2}\right)$}
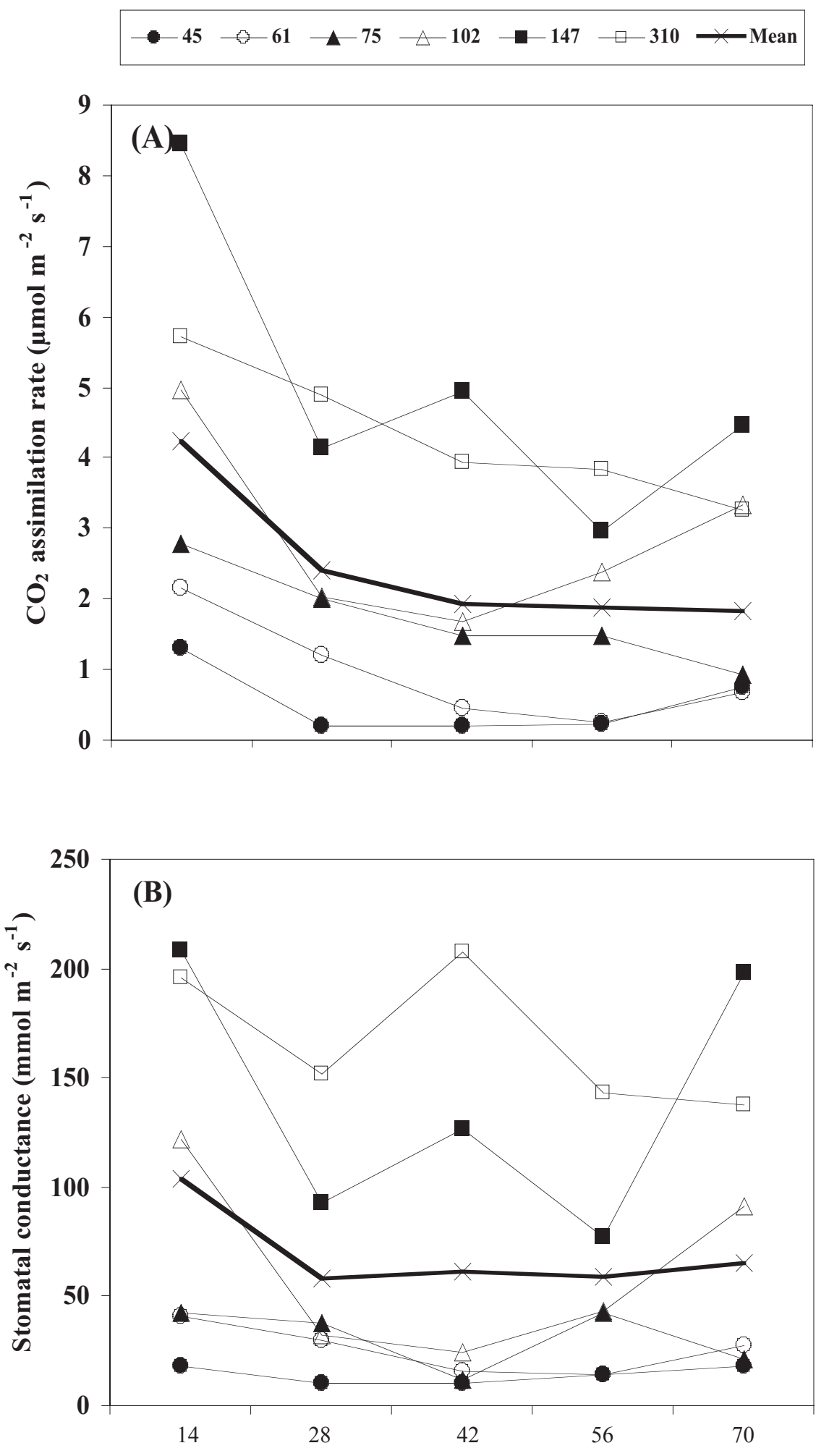

Days after setting

Fig. 4. (A) Photosynthetic rate $\left(\mathrm{A}_{\text {ambient }}\right)$ and (B) stomatal conductance $\left(\mathrm{g}_{\mathrm{s}}\right)$ of nonrooted, juvenile, softwood stem cuttings of loblolly pine in Expt. 2 (June 2002) 14, 28, 42, 56, or $70 \mathrm{~d}$ after setting (DAS) for each mist level. Symbols are means of measurements recorded in the AM or PM for two replications of each mist level. between -1.3 and $-0.9 \mathrm{MPa}$, and then sharply $\left(150 \mathrm{mmol} \cdot \mathrm{m}^{-2} \cdot \mathrm{s}^{-1}\right)$ thereafter until reaching $-0.5 \mathrm{MPa}$ (Fig. 6B).

Stomatal conductance affected $\mathrm{A}_{\text {ambient }}$ in nonrooted stem cuttings similarly at 28 and 70 DAS (Fig. 7A). In rooted controls 28 DAS, the response was similar to nonrooted stem cuttings measured at the same time (compare solid symbols between Fig. 7A and B). At 70 DAS, however, overall rates of $\mathrm{A}_{\text {ambient }}$ and $\mathrm{g}_{\mathrm{s}}$ were greater for the controls (Fig. 7A and B, compare open symbols). When data for both 28 and 70 DAS were included in the model for the controls, there was a strong overall relationship between $\mathrm{A}_{\text {ambient }}$ and $\mathrm{g}_{\mathrm{s}}$ (Fig. 7B, both open and solid symbols).

Relationships between rooting percentage and $A_{\text {ambient }}$ and $g_{s}$ (Expt. 2). Rooting percentage was not related to $\mathrm{A}_{\text {ambient }}$ of nonrooted, juvenile, succulent, stem cuttings of loblolly pine (Fig. $8 \mathrm{~A}$ ). Rooting percentage was related to the linear and quadratic terms of $g_{s}$ (Fig. 8B). The equation predicted $\geq 70 \%$ rooting when $\mathrm{g}_{\mathrm{s}}$ ranged from 40 to $150 \mathrm{mmol} \cdot \mathrm{m}^{-2} \cdot \mathrm{s}^{-1}$.

\section{Discussion}

Effect of mist level on VPD and VPD on $\Psi_{\text {cut }}$ and rooting percentage (Expt. 1). Mist level contributed to both the VPD surrounding the stem cuttings and $\Psi$ when data for both variables were averaged between 1000 and 1800 HR. Mist application decreases VPD by lowering leaf temperatures and increasing the RH surrounding stem cuttings (Tukey, 1978). Thus, there is less of a transpirational demand on stem cuttings and/or increased absorption of water through the foliage; both of which aid in maintaining or increasing $\Psi$ during the rooting period (LeBude et al., 2004).

Rooting $\geq 80 \%$ occurred for juvenile hardwood stem cuttings of loblolly pine when mean $\Psi_{\text {cut }}$ was maintained between -0.6 and -1.2 $\mathrm{MPa}$. This corresponded to a mean daily VPD between 0.60 and $0.85 \mathrm{kPa}$. Values of mean VPD associated with increased rooting are similar to those of Newton etal.(1992) when stem cuttings of terminalia (Terminalia spinosa Engl.) rooted at $80 \%$. In light red meranti (Shorea leprosula Miq.), rooting was $60 \%$ within this range of VPD; however, higher maximum VPDs were recorded during rooting, which could have corresponded to increased water stress (Aminah et al., 1997).

Mean daily maximum VPD recorded in the present study was between 0.85 and $1.25 \mathrm{kPa}$ when rooting percentage was $\geq 80 \%$. Because individual species may respond differently to VPD, an initial step in designing suitable rooting environments would be to define the physiological response and rooting of stem cuttings to such environmental factors. After rooting percentage was $100 \%$ in stem cuttings of poinsettia, VPD was used as a dynamic control for mist application during subsequent root growth and development (Zolnier et al., 2003). Our data indicate the potential use of VPD to control mist application during the period of adventitious root formation in dormant, hardwood stem cuttings of loblolly pine to produce a range of $\Psi_{\text {cut }}$ necessary for optimal 

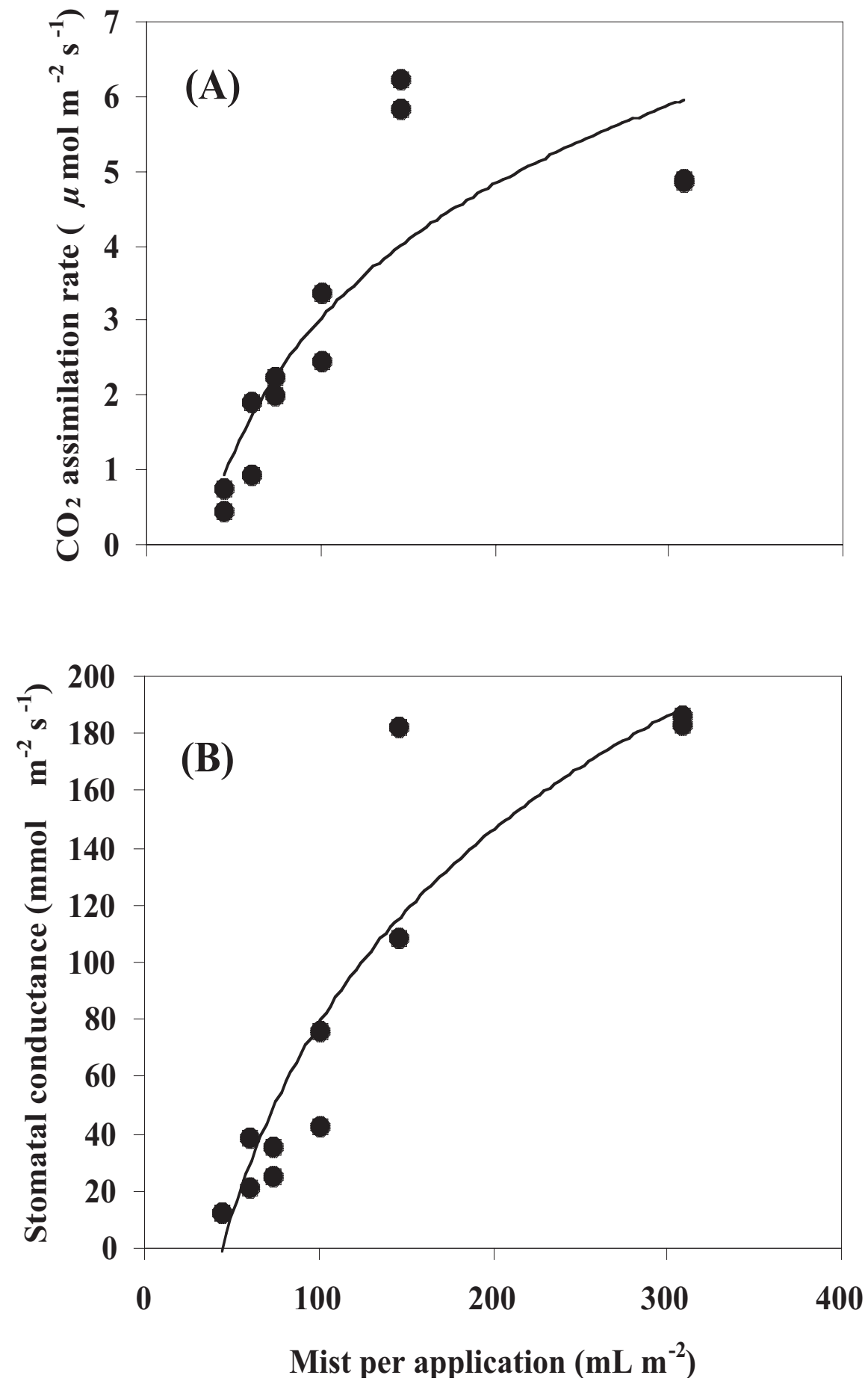

Fig. 5. Relationship between $(\mathbf{A})$ photosynthetic rate $\left(\mathrm{A}_{\text {ambient }}\right)$ and $(\mathbf{B})$ stomatal conductance $\left(\mathrm{g}_{\mathrm{s}}\right)$ and mist level for nonrooted, juvenile, softwood stem cuttings of loblolly pine rooted under six mist regimes in Expt. 2 (June 2002). Data points are averaged over AM and PM measurements 14, 28, or $42 \mathrm{~d}$ after setting (DAS). The regression equations are $(\mathbf{A}) \mathrm{A}_{\text {ambient }}=-9.03+2.61 \ln \left(\mathrm{mist} \mathrm{mL} \cdot \mathrm{m}^{-2}\right), P=0.01, r^{2}=$ 0.73 , and $(\mathbf{B}) \mathrm{g}_{\mathrm{s}}=-367.55+98.51 \ln \left(\right.$ mist $\left.\mathrm{mL} \cdot \mathrm{m}^{-2}\right), P=0.01, r^{2}=0.87$.

rooting rates. Data for VPD were unavailable for succulent, softwood stem cuttings in Expt. 2 due to instrument malfunction; however, the authors believe that the results for hardwood stem cuttings would extend to softwood stem cuttings because of 1) the strong relationships between VPD and $\Psi_{\text {cut }}$, and VPD and rooting of dormant stem cuttings in this paper, and 2) the strong and very similar relationship between rooting and $\Psi_{\text {cut }}$ of both dormant and succulent stem cuttings in LeBude et al. (2004).
Effect of miston $A_{\text {ambient }}$ and $g_{s}$, and their effect on rooting percentage (Expt. 2). $\mathrm{A}_{\text {ambient }}$ and $\mathrm{g}_{\mathrm{s}}$ of juvenile, nonrooted, succulent, stem cuttings of loblolly pine declined as DAS progressed, which has been reported for many species (Aminah et al., 1997; Davis, 1988; Mesén et al., 1997; Newton et al., 1992; Smalley et al., 1991; Yue and Margolis, 1993), especially when compared to rooted controls in the same experiment (Gay and Loach, 1977; Grossnickle and Russell, 1993). More broadly, these processes are decreased when our results are compared to those of 1- to 2-year-old intact seedlings of loblolly pine grown in the field in other experiments (Kramer and Clark, 1947; Seiler and Johnson, 1985). Both processes increased, however, with increasing mist volume (Fig. 5A and $\mathrm{B}$ ). This was probably due to the strong affect of mist level on $\Psi_{\text {cut }}$ (Fig. 5, LeBude et al., 2004), and the subsequent effect of $\Psi_{\text {cut }}$ on the relationship between $\mathrm{A}_{\text {ambient }}$ and $\mathrm{g}_{\mathrm{s}}$ (Figs. 6A and $B$ and 7A and $B$ ). In stem cuttings of other species, variation among treatments or decreases in photosynthetic rate were attributed generally to water deficit (Svenson et al., 1995), to water deficit induced by high irradiance (Mesén et al., 1997), or to water deficit induced by various leaf area treatments (Newton etal., 1992). This is not surprising since the dual roles of stomata are to regulate water loss while assimilating $\mathrm{CO}_{2}$. In some species, stomatal regulation is a response to water deficit (Sperry, 2000).

Photosynthetic rate of juvenile, nonrooted, succulent stem cuttings of loblolly pine was not related to rooting percentage. Some previous reports have also noted no relationship between photosynthetic rates during the rooting period and rooting percentage(Mesén etal., 1997; Okoroand Grace, 1976; Smalley et al., 1991; Svenson et al., 1995). Moreover, efforts to increase rooting of stem cuttings of loblolly pine by increasing levels of $\mathrm{CO}_{2}$ artificially in polyethylene greenhouses werenot successful in the 1970s [Michael Greenwood, Dept. of Forest Ecosystem Sci., Univ. of Maine, Orono (personal communication)]. In studies where photosynthetic rates among treatments were not related to percent rooting, such factors as the phase change of the stock plants (Grossnickle and Russell, 1993), clonal differences in rooting (von Schaesberg et al., 1993), or poor environmental conditions were inferred to be contributing causes (Yue and Margolis, 1993). It has been proposed that photosynthesis does not occur in nonrooted stem cuttings because of minimal leaf conductance (Gay and Loach, 1977). In contrast, other researchers have found that the photosynthetic rate in stem cuttings of tropical tree species affected rooting percentage (Aminah et al., 1997; Hoad and Leakey, 1996; Newton et al., 1992). Additional support for this hypothesis comes from Leakey and Coutts (1989) who measured levels of carbohydrates and correlated them with rooting percentage. Rooting percentages in that study, however, also could have been explained by differences in water deficits among treatments rather than as a direct result of photosynthetic activity.

The hypothesis that current photosynthetic rate affects rooting percentage has neither been proven nor refuted, as it is supported in some cases but not in others. This might be due to the inherent obstacle of independently controlling the photosynthetic rates of stem cuttings (Davis, 1988), in addition to the difficulty of replicating experiments over time, the use of various angiosperms vs. gymnosperms, as well as the use of different genetic experimental units within species (i.e., number of different cultivars, clones, or the use of seedlings). Moreover, in the present study, gas exchange was measured on succulent rather than dormant stem cuttings because it was thought 

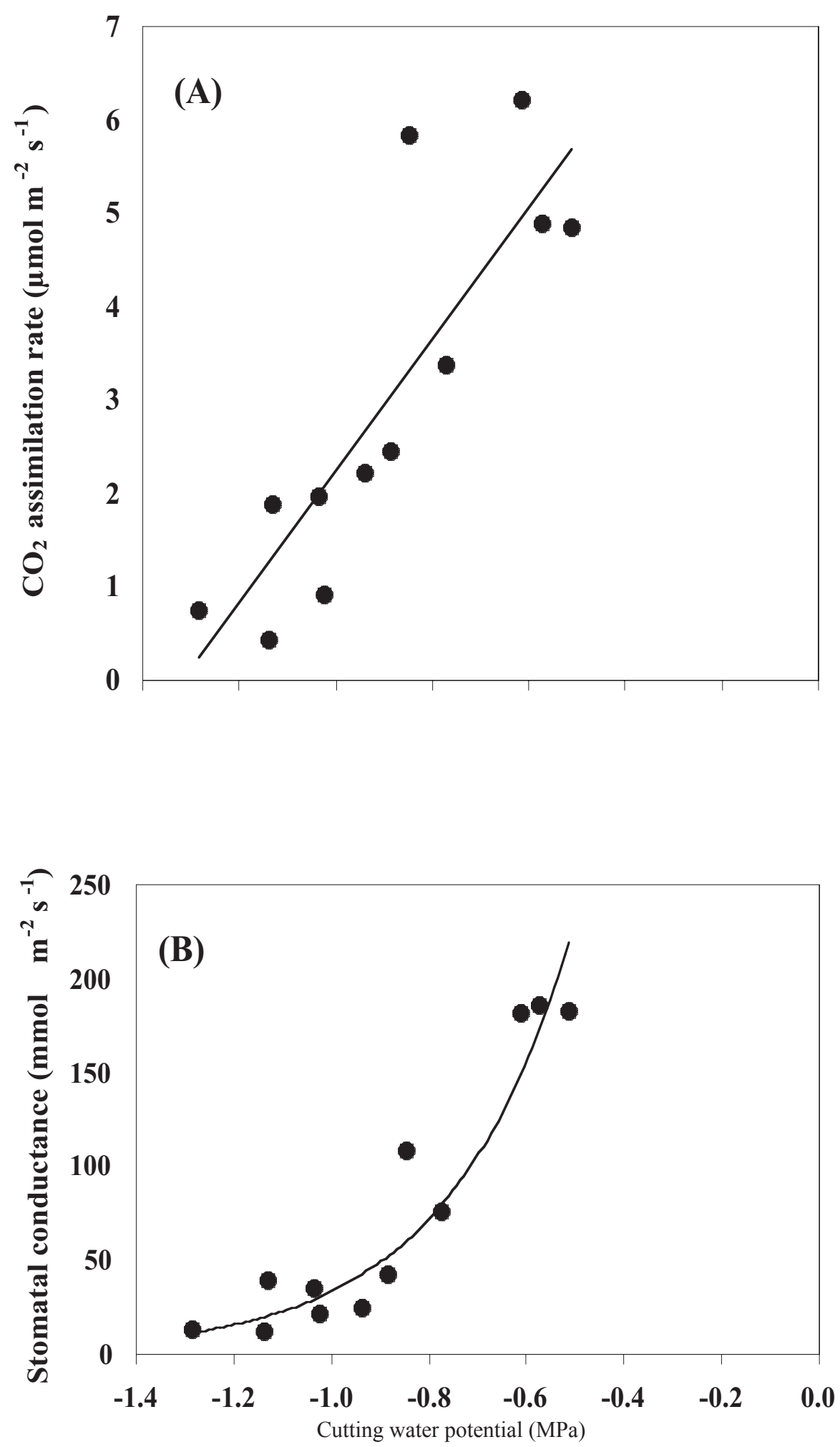

Fig. 6. Relationship between (A) photosynthetic rate $\left(\mathrm{A}_{\text {ambient }}\right)$ and (B) stomatal conductance $\left(\mathrm{g}_{\mathrm{s}}\right)$ and $\Psi_{\text {cut }}$ of nonrooted softwood stem cuttings of loblolly pine in Expt. 2 (June 2002). $\Psi_{\text {cut }}$ was measured on each cutting immediately after $\mathrm{A}_{\text {ambient }}$ and $\mathrm{g}_{\mathrm{s}}$ were measured. Data points for both variables are averaged over morning and afternoon measurements 14,28 , or $42 \mathrm{~d}$ after setting (DAS). The regression equations are (A) $\mathrm{A}_{\text {ambient }}=9.28+7.07\left(\Psi_{\text {cut }}\right), P=0.01, r^{2}=0.73$, and $(\mathbf{B}) \mathrm{g}_{\mathrm{s}}=36.11-219.39 \ln \left(\Psi_{\text {cut }} \times\right.$ $-1), P=0.01, r^{2}=0.86$. that succulent stem cuttings would be more photosynthetically active than dormant stem cuttings. We suggest that photosynthesis in juvenile, succulent, stem cuttings of loblolly pine, at least at a minimal level, might be an indication of the relative ability of cuttings to function under conditions of high stress. In this case, it is an indication of the ability of the stem cutting to assimilate carbon while experiencing repeated severe water deficit coupled with high leaf temperatures and irradiance. Above that minimal level, water deficit, photosynthesis and, therefore, carbohydrate supply are not limiting to rooting percentage.

In the present investigation, rooting percentage was more closely related to moderate rates of $g_{s}$ than to $A_{\text {ambient }}$ in softwood, juvenile stem cuttings of loblolly pine. Rooting percentage and $g_{s}$ could be related indirectly as indicated by the inability of the linear and quadratic equation to predict more than about $50 \%$ of the variation in rooting percentage (Fig. 8B). Stomatal conductance could be related indirectly to rooting percentage by moderating $\Psi_{\text {cut }}$. The mechanism(s) by which $\Psi_{\text {cut }}$ influence rooting percentage is largely unknown (LeBude et al., 2004; Sinclair and Ludlow, 1985), but this effect could be independent of any effect $g_{s}$ has on rooting percentage.

Summary. This study measured various environmental variables and physiological processes to learn how to better design and control rooting environments for stem cuttings of loblolly pine. Although $\mathrm{A}_{\text {ambient }}, \mathrm{g}_{\mathrm{s}}, \Psi_{\text {cut }}$, and VPD were affected by varying mist levels, the relationships between $\mathrm{A}_{\text {ambient }}$ and $\mathrm{g}_{\mathrm{s}}$ with rooting percentage were not as strong as between $\Psi_{\text {cut }}$ and VPD with rooting percentage. Moreover, $\mathrm{A}_{\text {ambient }}, \mathrm{g}_{\mathrm{s}}$, and $\Psi$ are time consuming measurements, limiting the number of measurements that can be taken and their subsequent simultaneous use in dynamic control of mist application. On the other hand, VPD was related strongly to rooting percentage, and VPD can be measured rapidly, calculated automatically, and integrated into a system to control mist application dynamically. Our results suggest that VPD could be used as a dynamic control for mist application when managing $\Psi_{\text {cut }}$ in stem cuttings of loblolly pine. A mean daily range of VPD between 1000 and $1800 \mathrm{HR}$ of 0.6 to $0.85 \mathrm{kPa}$ should produce beneficial levels of $\Psi_{\text {cut }}$ that improve rooting percentages in stem cuttings of loblolly pine. Further research is necessary to validate the VPD-based model as a control system for mist application, as well as establish appropriate levels of VPD for a wider range of species in different rooting environments.

\section{Literature Cited}

Aminah, H., J. McP. Dick, and J. Grace. 1997. Influence of irradiance on water relations and carbon flux during rooting of Shorea leprosula leafy stem cuttings. Tree Physiol. 17:445-452. 
Buck, A.L. 1981. New equations for computing vapor pressure and enhancement factor. J. Appl. Meteorol. 20:1527-1532.

Davis, T.D. 1988. Photosynthesis during adventitious rooting, p. 79-87. In:T.D. Davis, B.E. Haissig, and N. Sankhla (eds.). Adventitious root formation in cuttings. Dioscorides Press, Portland, Ore.

Frampton, J., F. Isik, and B. Goldfarb. 2002. Effects of nursery characteristics on field survival and growth of loblolly pine rooted cuttings. S. J.Appl. For. 26:207-213.

Frampton, J., B. Li, and B. Goldfarb. 2000. Early field growth of loblolly pine rooted cuttings and seedlings. S. J. Appl. For. 24:98-105.

Gay, A.P. and K. Loach. 1977. Leaf conductance changes on leafy cuttings of Cornus and Rhododendron during propagation. J. Hort. Sci. 52:509-516.

Gocke, M.H. 2001. Effects of three propagation systems on survival, growth and morphology of loblolly and sweetgum rooted cuttings. Proc. 26th Biennial S. Forest Tree Improv. Conf. p. 15.

Grossnickle, S.C. and J.H. Russell. 1993. Water relations and gas exchange processes of yellow-cedar donor plants and cuttings in response to maturation. Forest Ecol. Mgt. 56:185-198.

Hartmann, H.T., D.E. Kester, F.T. Davies, Jr., and R.L. Geneve. 2002. Hartmann and Kester's plant propagation: Principles and practices. 7th ed. Prentice Hall, Upper Saddle River, N.J.

Hoad, S.P. and R.R.B. Leakey. 1996. Effects of preseverance light quality on the vegetative propagation of Eucalyptus grandis W. Hill ex Maiden 10:317-324.

Isik, F., B. Li, J. Frampton, and B. Goldfarb. 2004. Efficiency of seedlings and rooted cuttings for testing and selection in Pinus taeda. Forest Sci. 50:44-53.

Johnson, J.D. 1984. A rapid technique for estimating total surface area of pine needles. Forest Sci. 30:913-921.

Kramer, P.J. and W.S. Clark. 1947. A comparison of photosynthesis in individual pine needles and entire seedlings at various light intensities. Plant Physiol. 22:51-57.

Leakey, R.R.B. and M.P.Coutts. 1989. The dynamics of rooting in Triplochiton scleroxylon cuttings: Their relation to leaf area, node position, dry weight accumulation, leaf water potential and carbohydrate composition. Tree Physiol. 5:135-146.

LeBude, A.V., B. Goldfarb, F.A. Blazich, J. Frampton, and F.C. Wise. 2004. Mist, substrate water potential, and cutting water potential influence rooting of stem cuttings of loblolly pine. Tree Physiol. 24:823-831.

Loach, K. and D.N. Whalley. 1978. Water and carbohydrate relationships during the rooting of cuttings. Acta Hort. 79:161-168.

Mesén, F., A.C. Newton, and R.R.B. Leakey. 1997. The effects of propagation environment and foliar area on the rooting physiology of Cordia alliodora (Ruiz \& Pavon) Oken cuttings. Trees 11:404-411.

Newton, A.C., P.N. Muthoka, and J. McP. Dick. 1992. The influence ofleafarea on the rooting physiology of leafy stem cuttings of Terminalia spinosa Engl. Trees 6:210-215.

Okoro, O.O. and J. Grace. 1976. The physiology of rooting Populus cuttings. I. Carbohydrates and photosynthesis. Physiol. Plant. 36:133-138.

Prenger, J.J. and P.P. Ling. 2001. Greenhouse condensation control: Understanding and using vapor pressure deficit (VPD). Ohio State Univ. Ext. Factsheet. 26 Feb. 2003. <http://ohioline.osu. edu/aex-fact/0804.html>.

Pullman G.S., S. Johnson, G. Peter, J. Cairney, and N. Xu. 2003. Improving loblolly pine somatic embryo maturation: Comparison of somatic and zygotic embryomorphology, germination, and gene
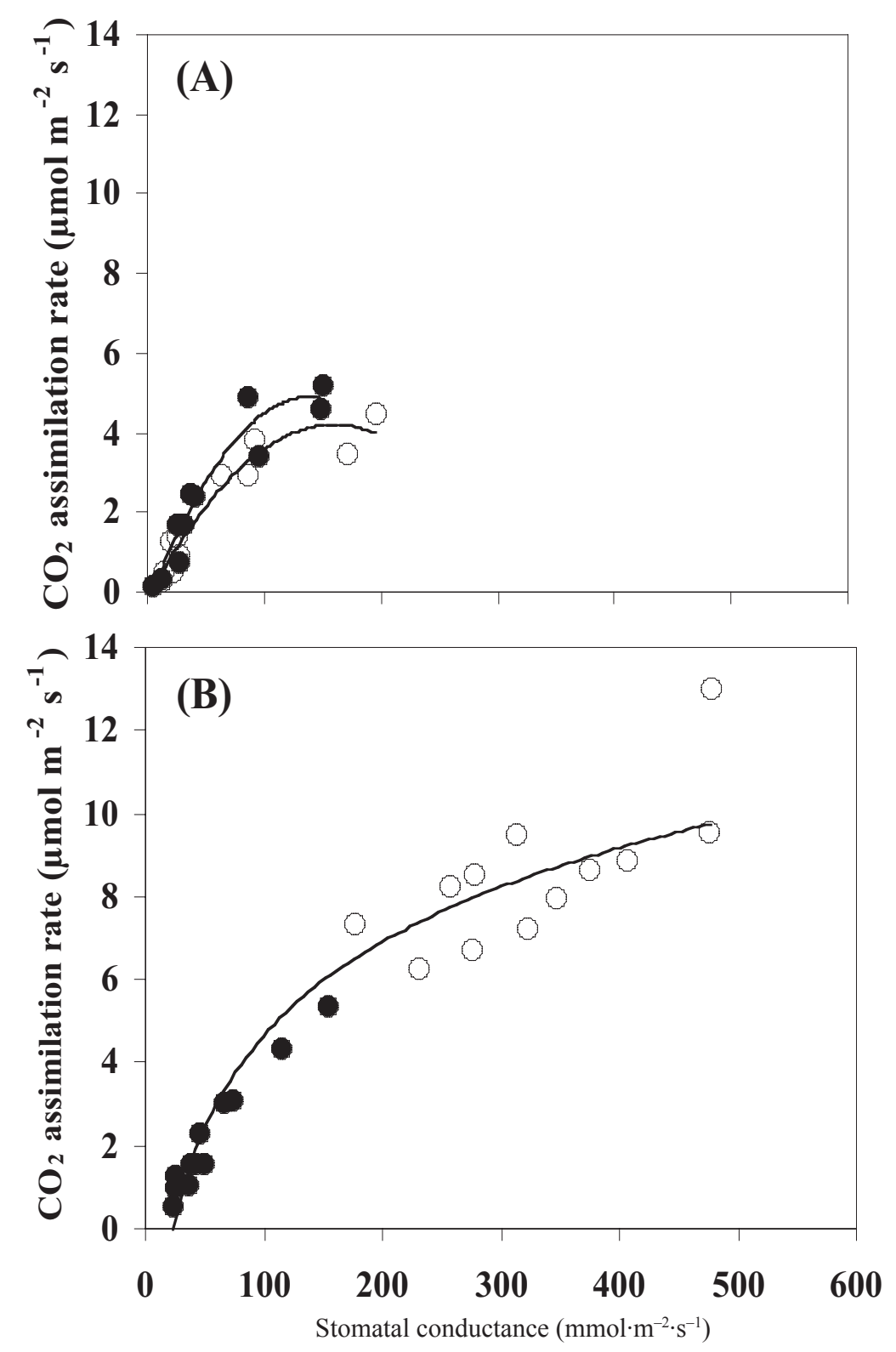

Fig. 7. Relationship between photosynthetic rate $\left(\mathrm{A}_{\text {ambient }}\right)$ and stomatal conductance $\left(\mathrm{g}_{\mathrm{s}}\right)$ for $(\mathbf{A})$ nonrooted, juvenile, softwood stem cuttings of loblolly pine 28 (solid symbols) and 70 (open symbols) d after setting (DAS) and (B) rooted controls at 28 (solid symbols) and 70 (open symbols) DAS in Expt. 2 (June 2002). The regression equations are $(\mathbf{A}) \mathrm{A}_{\text {ambient }}(28 \mathrm{DAS})=-0.27+0.05\left(\mathrm{~g}_{\mathrm{s}}\right)-0.0002\left(\mathrm{~g}_{\mathrm{s}}^{2}\right), P=0.01$, $r^{2}=0.92$, and $\mathrm{A}_{\text {ambient }}(70 \mathrm{DAS})=-0.43+0.08\left(\mathrm{~g}_{\mathrm{s}}\right)-0.0003\left(\mathrm{~g}_{\mathrm{s}}^{2}\right), P=0.01, r^{2}=0.92$ for nonrooted stem cuttings and $($ B $) \mathrm{A}_{\text {ambient }}(28$ and $70 \mathrm{DAS})=-7.9+2.91 \ln \left(\mathrm{g}_{\mathrm{s}}\right), P=0.01, r^{2}=0.80$ for rooted controls.

expression. Plant Cell Rpt. 21:747-758.

SAS Institute, Inc. 2001. Version 8.2. SAS Inst., Inc., Cary, N.C.

Scholander, P.F., E.D. Bradstreet, and E.A. Hemmingsen. 1965. Sap pressure in vascular plants. Science 148:339-346.

Seiler, J.R. and J.D. Johnson. 1985. Photosynthesis and transpiration of loblolly pine seedlings as influenced by moisture-stress conditioning. For. Sci. 31:742-749.

Sinclair, T.R. and M.M. Ludlow. 1985. Who taught plants thermodynamics? The unfulfilled potential of plant water potential. Austral. J. Plant Physiol. 12:213-217.

Smalley, T.J., M.A. Dirr, A.M. Armitage, B.W. Wood, R.O. Teskey, and R.F. Severson. 1991. Photosynthesis and leaf water, carbohydrate, and hormone status during rooting of stem cuttings of Acer rubrum. J. Amer. Soc. Hort. Sci. 116:1052-1057.
Sperry, J.S. 2000. Hydraulic constraints on plant gas exchange. Agr. Forest Meteorol. 104:13-23.

Steel, R.G.D., J.H. Torrie, and D.A. Dickey. 1997. Principles and practices of statistics: Abiometrical approach. 3rd ed. McGraw-Hill, New York.

Svenson, S.E. and F.T. Davies, Jr. 1992. Comparison of methods for estimating surface area of water-stressed and fully hydrated pine needle segments for gas exchange analysis. Tree Physiol. 10:417-421.

Svenson, S. E., F.T. Davies, Jr., and S.A. Duray. 1995. Gas exchange, water relations, and dry weight partitioning during root initiation and development of poinsettia cuttings. J. Amer. Soc. Hort. Sci. 120:454 459 .

Tukey, Jr., H.B. 1978. The effects of intermittent mist on cuttings. Propagation and raising of nursery stock. Acta Hort. 79:49-56.

von Schaesberg, N., G. Ebert, and P. Lüdders. 1993. Leaf gas exchange of mango (Mangifera indica 

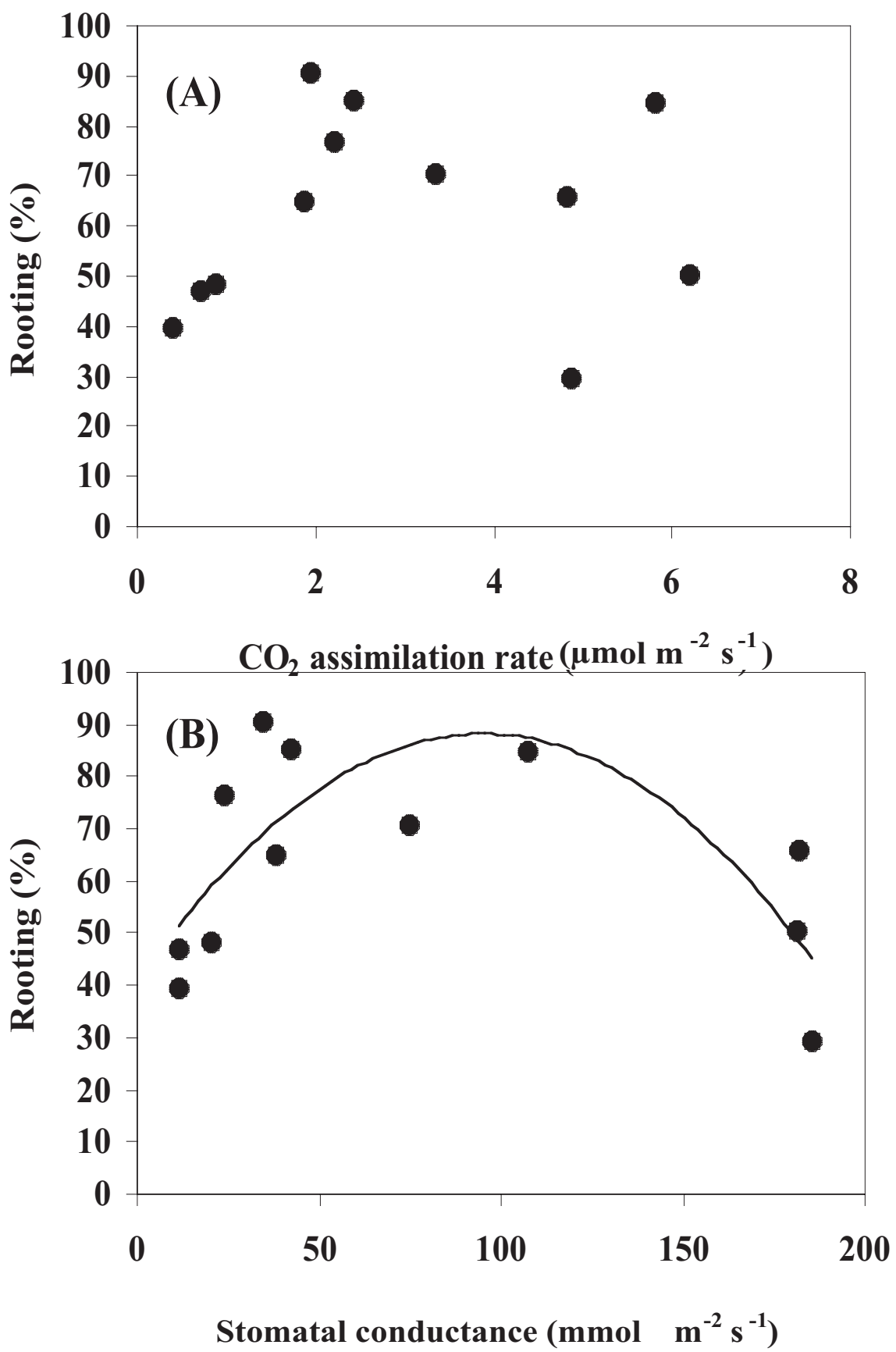

Fig. 8. Rooting percentage and (A) photosynthetic rate $\left(\mathrm{A}_{\text {ambint }}\right)$ and $(\mathbf{B})$ stomatal conductance $\left(\mathrm{g}_{\mathrm{s}}\right)$ of nonrooted, juvenile, softwood stem cuttings averaged for AM or PM measurements recorded 14, 28, or $42 \mathrm{~d}$ after setting (DAS) in Expt. 2 (June 2002). Rooting percentage (70 DAS) was not significantly related to photosynthetic rate. The regression equation in $\mathbf{B}$ is rooting $(\%)=34.48+1.55\left(\mathrm{~g}_{\mathrm{s}}\right)-0.007\left(\mathrm{~g}_{\mathrm{s}}\right.$ $\left.{ }^{2}\right), P=0.04, r^{2}=0.52$.

L.) cuttings during adventitious root formation. Angew. Bot. 67:14-16.

Yue, D. and H.A. Margolis. 1993. Photosynthesis and dark respiration of black spruce cuttings during rooting in response to light and temperature. Can. J. For. Res. 23:1150-1155.

Zobel, B.J. and J. Talbert. 1984. Applied forest tree improvement. Wiley, New York.

Zolnier, S., R.S. Gates, R.G.Anderson, S.E. Nokes, and G.A. Duncan. 2001a. Non-water stressed baseline as a tool for dynamic control of a misting system for propagation of poinsettias. Trans. Amer. Soc. Agr. Eng. 44:137-147.

Zolnier, S., R.S. Gates, R.L. Geneve, and J.W. Buxton 2001b. Surface diffusive resistance of rooted poinsettia cuttings under controlled-environment conditions. Trans. Amer. Soc. Agr. Eng. 44:1779-1787.

Zolnier, S., R.S. Gates, R.L. Geneve, and J.W.Buxton. 2003. Evapotranspiration-based misting control for poinsettia cuttings. Trans. Amer. Soc. Agr. Eng. 46:135-145. 